\title{
Chemical Constituents of the Terrestrial Stems of Ephedra sinica and their PPAR-y Ligand-Binding Activity
}

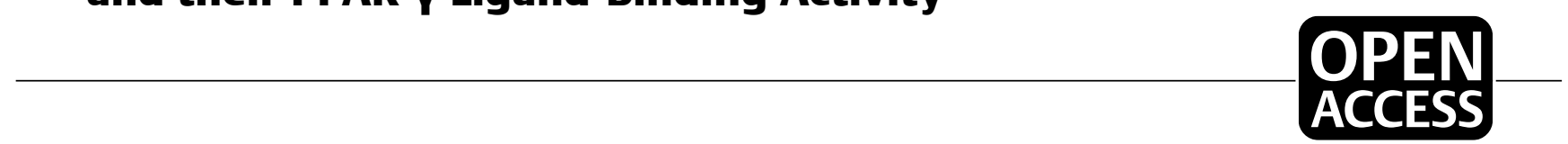

(c) (1) (우 $\ominus$

\author{
Authors \\ Yukiko Matsuo', Mayu Sasaki ${ }^{1}$, Haruhiko Fukaya', Katsunori Miyake", Riko Takeuchi², Hidetoshi Kumata², \\ Yoshihiro Mimaki ${ }^{1}$
}

\author{
Affiliations \\ 1 School of Pharmacy, Tokyo University of Pharmacy and \\ Life Science, Hachioji, Japan \\ 2 School of Life Sciences, Tokyo University of Pharmacy \\ and Life Science, Hachioji, Japan \\ Key words \\ Ephedra sinica, Ephedraceae, sesquiterpene, bisabolane, \\ flavonoid, PPAR-y

$\begin{array}{ll}\text { received } & 04.11 .2019 \\ \text { revised } & 17.12 .2019 \\ \text { accepted } & 06.01 .2020\end{array}$ \\ Bibliography \\ DOI https://doi.org/10.1055/a-1094-9229 \\ Planta Med Int Open 2020; 7: e12-e16 \\ (c) Georg Thieme Verlag KG Stuttgart · New York \\ ISSN 2509-9264
}

\author{
Correspondence \\ Dr. Yukiko Matsuo \\ School of Pharmacy, Tokyo University of Pharmacy and Life \\ Science \\ 1432-1 Horinouchi \\ 192-0392 Hachioji \\ Japan \\ matsuoy@toyaku.ac.jp
}

Supporting Information for this article is available online at: http://www.thieme-connect.de/products.

\begin{abstract}
Bioassay-guided fractionation of the $\mathrm{MeOH}$ extract of Ephedra sinica terrestrial stems, using a PPAR-y ligand binding assay, resulted in the isolation of 10 compounds, including one new bisabolane-type sesquiterpenoid (10). The structure of the new compound was determined by extensive spectroscopic analysis, including two-dimensional (2D) NMR. Among the isolated compounds, the sitosterol derivatives ( $\mathbf{1}$ and $\mathbf{2}$ ), flavonoid glucoside (7), and the new sesquiterpenoid (10), showed significant PPAR-y ligand-binding activity.
\end{abstract}

\section{Introduction}

Ephedra sinica is described in the Japanese Pharmacopoeia (17 th edition) as one of the original plants from which the crude drug Ephedra Herb has been obtained [1]. Ephedra Herb has long been used as an antitussive and expectorant in traditional Japanese medicine $[2,3]$. The terrestrial stems of E. sinica are well known to contain ephedrine alkaloids, (-)-ephedrine and (+)-pseudoephedrine, and tannins ephedrannin A and B [4-6]. The ephedrine alkaloids in Ephedra Herb are mainly responsible for exerting pharmaceutical effects as well as adverse effects [7, 8]. In addition, only a few bioactive constituents of Ephedra Herb, except for ephedrine alkaloids, have been reported [9]. Pharmacological studies of minor constituents of Ephedra Herb, such as sesquiterpenes and monoterpenes, are needed. As part of our continuous search for bioactive secondary metabolites of traditional medicines, a $\mathrm{MeOH}$ extract of $E$. sinica was found to exhibit peroxisome proliferator-activated receptor (PPAR)- $\gamma$ ligand-binding activity. To identify the secondary metab- olites in E. sinica having PPAR-y ligand-binding activity, bioassayguided fractionation of the $\mathrm{MeOH}$ extract of $E$. sinica terrestrial stems was carried out. This led to the isolation of 10 compounds (1-10), including a new bisabolane-type sesquiterpenoid (10) ( $\vee$ Fig. 1). This paper is a report on the structural determination of the new sesquiterpene obtained by extensive spectroscopic analysis, including 2D NMR data. The isolated compounds were evaluated for their PPAR-y ligand-binding activity.

\section{Results and Discussion}

The terrestrial stems of $E$. sinica ( $5.4 \mathrm{~kg}$ dry weight) were extracted with $\mathrm{MeOH}$ at $50^{\circ} \mathrm{C}$. After removing the solvent, the $\mathrm{MeOH}$ extract $(665 \mathrm{~g})$ was applied to a porous polymer polystyrene resin (Diaion $\mathrm{HP}$-20) column. The $\mathrm{MeOH}$, EtOH, and EtOAc-eluted portions showed PPAR- $y$ ligand-binding activity ( $\triangleright$ Fig. 2 ). Thus, the $\mathrm{MeOH}$ and $\mathrm{EtOH}$-soluble fractions were passed through column chroma- 


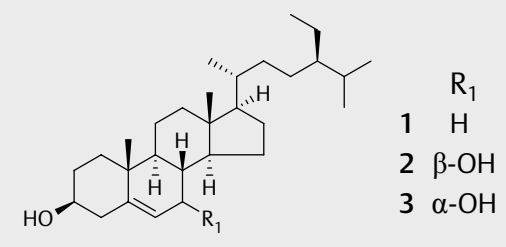

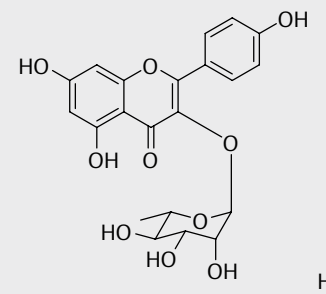

4
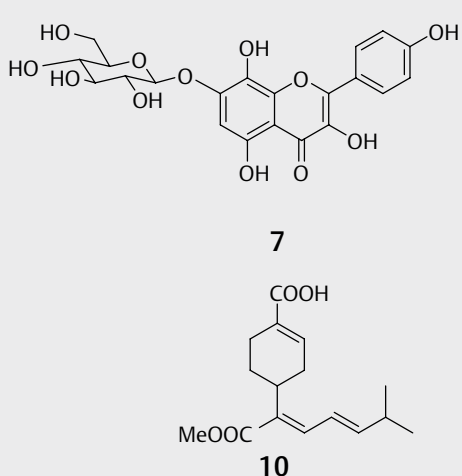

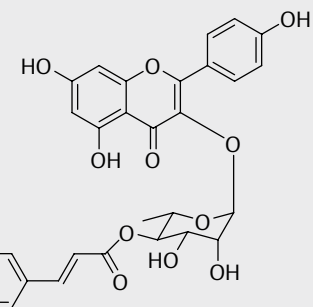

5

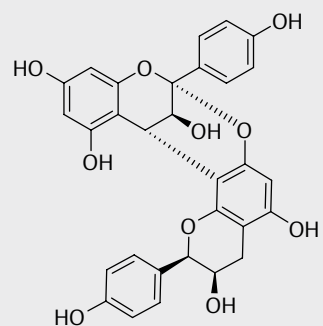

8
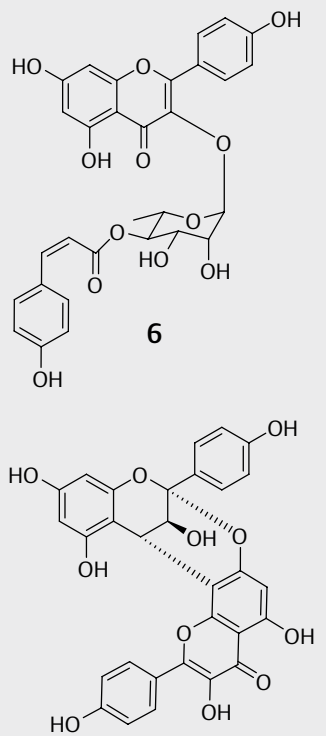

9

$\checkmark$ Fig. 1 Isolated compounds from E. sinica.

tography on silica gel and octadecylsilanized (ODS) silica gel producing compounds $\mathbf{1 - 1 0}$. Compounds $\mathbf{1 - 9}$ were identified as $\beta$-sitosterol (1) [10], 7 $\beta$-hydroxysitosterol (2) [11], 7 $\alpha$-hydroxysitosterol (3) [11], kaempferol-3-O-rhamnoside (4) [12], kaempferol-3-O-(4"-trans-p-coumaroyl)-rhamnopyranoside (5) [13], kaempferol-3-O-(4"-cis-p-coumaroyl)-rhamnopyranoside (6) [14], herbacetin-7-O-glucopyranoside (7) [6], mahuanin A (8) [15], and ephedrannin $\mathrm{A}(\mathbf{9})$ [16], respectively ( $\mathbf{F i g . 1}$ ).

Compound $10\left(\mathrm{C}_{16} \mathrm{H}_{22} \mathrm{O}_{4}\right)$ was obtained as a colorless oil, which was determined by high-resolution electrospray ionization timeof-flight mass spectrometry (HR-ESI-TOF-MS, m/z 301.1413 [M + $\mathrm{Na}]^{+}$, calcd. for $\mathrm{C}_{16} \mathrm{H}_{22} \mathrm{NaO}_{4} 301.1416$ ) and ${ }^{13} \mathrm{C} \mathrm{NMR} \mathrm{(16}$ carbon signals) data. The IR spectrum of $\mathbf{1 0}$ showed absorption bands of carbonyl groups at 1700 and $1644 \mathrm{~cm}^{-1}$. The ${ }^{13} \mathrm{C}$ NMR spectrum exhibited two carbonyl carbon signals at $\delta_{C} 172.0$ and 168.1 , and the HMBC spectrum displayed a correlation peak between $\delta_{\mathrm{C}} 168.1$ and a methyl singlet signal at $\delta_{\mathrm{H}} 3.74$. On the other hand, treatment of 10 with bis(trimethylsilyl)trifluoroacetamide (BSTFA) in pyridine produced the corresponding trimethylsilyl (TMS) derivative of $\mathbf{1 0}$ $\left(\mathrm{C}_{19} \mathrm{H}_{30} \mathrm{O}_{4} \mathrm{Si}\right.$; GC/MS, m/z: 350.1 [M + TMS]). These data implied the presence of two carboxy groups in the molecule of $\mathbf{1 0}$, one is free and another is methyl ester. The ${ }^{1} \mathrm{H}$ NMR and ${ }^{1} \mathrm{H}-{ }^{1} \mathrm{H}$ COSY spectra disclosed the following spin-coupling correlations: $\delta_{H} 7.16$
$(\mathrm{H}-2) / 2.73(\mathrm{H}-3 \mathrm{a})$ and $2.20(\mathrm{H}-3 \mathrm{~b}) / 2.89(\mathrm{H}-4) / 2.12(\mathrm{H}-5 \mathrm{a})$ and 1.74 ( $\mathrm{H}-5 \mathrm{~b}) / 2.54(\mathrm{H}-6 \mathrm{a})$ and $2.24(\mathrm{H}-6 \mathrm{~b})$, and the $\mathrm{H}-2$ olefinic proton and $\mathrm{H}_{2}-6$ methylene protons showed long-range correlations with the quaternary olefinic carbon at $\delta_{C} 129.2$ (C-1) and the carbonyl carbon of the carboxy group at $\delta_{C} 172.0$ (C-7). These data provided evidence of the presence of a cyclohexene group bearing a carboxy group at $\mathrm{C}-1$. The other the spin-coupling correlations $\delta_{\mathrm{H}} 1.06(\mathrm{Me}-$ 14) and $1.05(\mathrm{Me}-15) / 2.44(\mathrm{H}-13) / 6.09(\mathrm{H}-12) / 6.35(\mathrm{H}-11) / 7.16$ $(\mathrm{H}-10)$ were consistent with a 4-methyl-2-pentene group. The $\mathrm{HMBC}$ correlations from $\mathrm{H}_{2}-3, \mathrm{H}-4, \mathrm{H}_{2}-5$, and $\mathrm{H}-11$ to the olefinic carbon at $\delta_{\mathrm{C}} 131.8$ (C-8) and from $\mathrm{H}-4$ to the carbonyl carbon of the methyl carboxylate group at $\delta_{C} 168.1$ (C-9) indicated that C-4 of the cyclohexene group, C-9 carbonyl group, and C-10 of the 4-methyl2-pentene group were linked to the $\mathrm{C}$-8 olefinic carbon, and a double bond was present between $\mathrm{C}-8$ and $\mathrm{C}-10$ ( $>$ Fig. 3). The spincoupling constant of $\mathrm{H}-10 / \mathrm{H}-11(\mathrm{~J}=11.4 \mathrm{~Hz})$ and $\mathrm{H}-11 / \mathrm{H}-12 \mathrm{~V}=$ $15.0 \mathrm{~Hz}$ ) and NOE correlations between $\mathrm{H}-10$ and $\mathrm{H}-12$ and between $\mathrm{H}-11$ and $\mathrm{H}_{2}-3$ allowed the geometry at $\mathrm{C}-8$ and $\mathrm{C}-11$ to be established as $8 E$ and $11 E$. In ESI-TOF/MS-MS analysis of 10, the prominent fragment ion-peak at $\mathrm{m} / \mathrm{z} 207$ originated from a loss of the $\mathrm{C}_{(11)} \mathrm{H}-\mathrm{C}_{(12)} \mathrm{H}-\mathrm{C}_{(13)} \mathrm{H}-\mathrm{Me}_{(14)}\left(\mathrm{Me}_{(15)}\right)$ moiety of $\mathbf{1 0}$. Other minor peaks observed at $m / z 245,235,233,201,179$, and 163 corresponded to the proposed fragments as depicted in the Supporting Informa- 


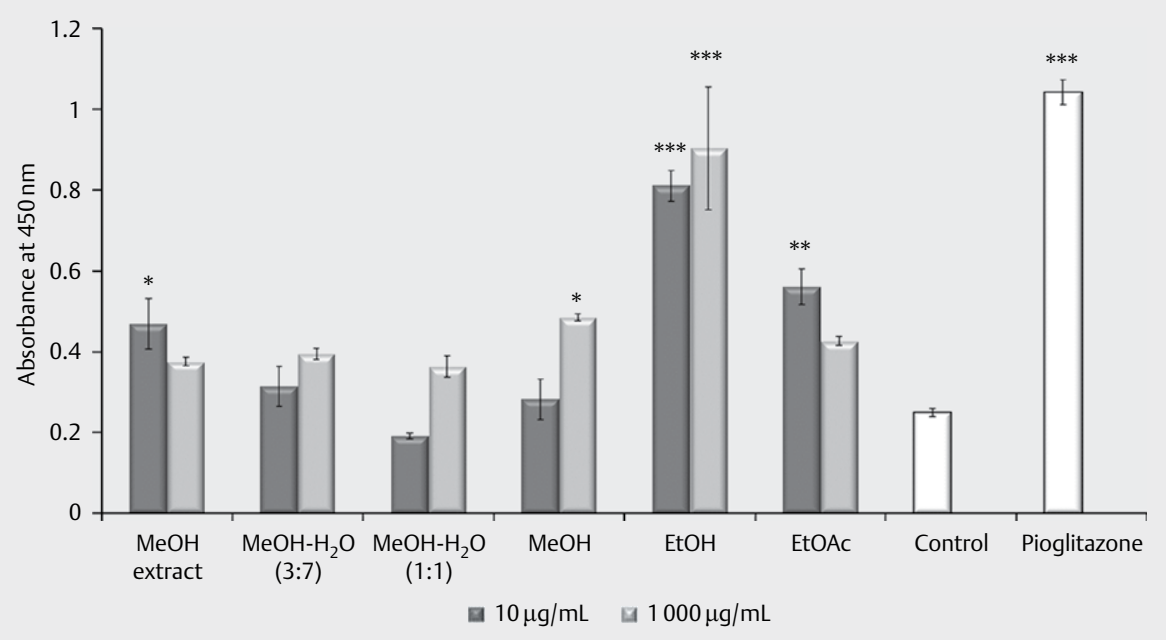

- Fig. 2 PPAR- $y$ ligand-binding activity of the MeOH extract of $E$. sinica and fractions. The PPAR- $y$ ligand-binding activity of each fraction was measured at sample concentrations of 1000 and $10 \mu \mathrm{g} / \mathrm{mL}$ and that of pioglitazone at $5.0 \mu \mathrm{M}$. Data are represented as the mean \pm SEM of three experiments performed in triplicate; ${ }^{* * *} \mathrm{p}<0.0001$ vs. control, ${ }^{* *} \mathrm{p}<0.001$ vs. control, $" \mathrm{p}<0.01$ vs. control.

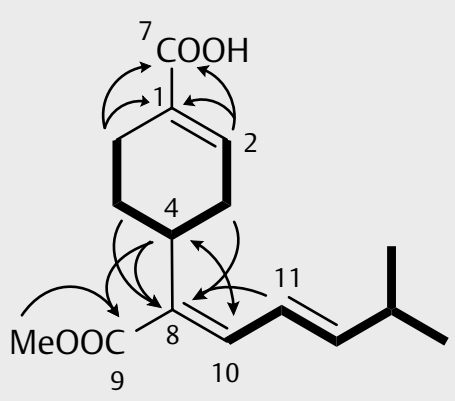

Fig. $3{ }^{1} \mathrm{H}-{ }^{1} \mathrm{H}$ COSY and selected HMBC correlations of $\mathbf{1 0}$.

tion. Thus, the structure of $\mathbf{1 0}$ was established as a bisabolane-type sesquiterpenoid as shown in $\mathbf{F i g . ~} \mathbf{1}$. Compound $\mathbf{1 0}$ showed no specific rotation and was assumed to be a racemate.

The isolated compounds $\mathbf{1 , 2}$, and $\mathbf{4 - 1 0}$ were evaluated for their PPAR- $y$ ligand-binding activity using a nuclear receptor cofactor assay system ( $\vee$ Fig. 4). Kaempferol was used as a positive control. Compounds 1, 2, 7, and 10 exhibited significant PPAR- $y$ ligandbinding activity, among which the new bisabolane-type sesquiterpenoid 10 was the most potent. In the kaempferol derivatives (47 ), the glycosylation at the C-2 hydroxy group by a rhamnosyl moiety (4-6) reduced the PPAR-y ligand activity.

In conclusion, a new bisabolane-type sesquiterpenoid (10) and nine known compounds (1-9) were isolated from the $\mathrm{MeOH}$ extract of E. sinica terrestrial stems. Compounds 1, 2, 7, and 10 showed significant PPAR- $y$ ligand-binding activity, among which the new bisabolane derivative $\mathbf{1 0}$ was the most potent. In a previous study, terpenoids with a cyclohexene ring were reported to act as a native retinoid $X$ receptor agonist [17]. With expectation, 10 exhibited PPAR-y ligand-binding activity.

\section{Materials and Methods}

\section{General experimental procedures}

The instruments and experimental conditions were the same as those described in a previous paper [18]. All solvents used for extraction and isolation were high grade (> 99\%) (Fujifilm Wako Pure Chemical). Purities of all isolated compounds (> $95 \%$ ) were confirmed by NMR and TLC analysis.

\section{Plant material}

The dried terrestrial parts $(5.4 \mathrm{~kg}$ ) of E. sinica Stapf (Ephedraceae) were collected from the Medicinal Plant Garden of the Tokyo University of Pharmacy and Life Sciences, Tokyo, Japan on July 10 , 2015. This genetic resource was introduced to the garden in December 1981. The plant material was authenticated by one of the authors (K. M.) and was also identified according to the ITS rDNA sequence [19]. A voucher specimen has been deposited in the Herbarium of Tokyo University of Pharmacy and Life Sciences (KS2015-001).

\section{Extraction and isolation}

The terrestrial stems of $E$. sinica $(5.4 \mathrm{~kg})$ were extracted with $\mathrm{MeOH}$ $(50 \mathrm{~L})$ at $50^{\circ} \mathrm{C}$. After evaporation of $\mathrm{MeOH}$ under reduced pressure at $40^{\circ} \mathrm{C}$, the $\mathrm{MeOH}$ extract $(665 \mathrm{~g})$ was subjected to a Diaion HP-20 column $(2200 \mathrm{~g}, 85 \mathrm{~mm}$ i.d. $\times 600 \mathrm{~mm})$ and successively partitioned by eluting with $\mathrm{MeOH}-\mathrm{H}_{2} \mathrm{O}$ (3:7), $\mathrm{MeOH}-\mathrm{H}_{2} \mathrm{O}(1: 1), \mathrm{MeOH}, \mathrm{EtOH}$, and EtOAc (each $10 \mathrm{~L}$ ) in order of decreasing polarity. The EtOHeluted fraction $(55 \mathrm{~g}$ ) was passed through a silica gel column $(2000 \mathrm{~g}, 85 \mathrm{~mm}$ i.d. $\times 600 \mathrm{~mm})$ eluted with gradient mixtures of hexane-EtOAc $(4: 1 ; 3: 1 ; 2: 1 ; 1: 1)$ and $\mathrm{MeOH}$, which produced 9 fractions (Frs. A-I). Fr. C was separated by a silica gel column $(1800 \mathrm{~g}, 80 \mathrm{~mm}$ i.d. $\times 400 \mathrm{~mm})$ eluted with hexane-EtOAc $(7: 1 ; 4: 1$; $1: 1)$ and, sequentially, an ODS silica gel column eluted with MeCN- 


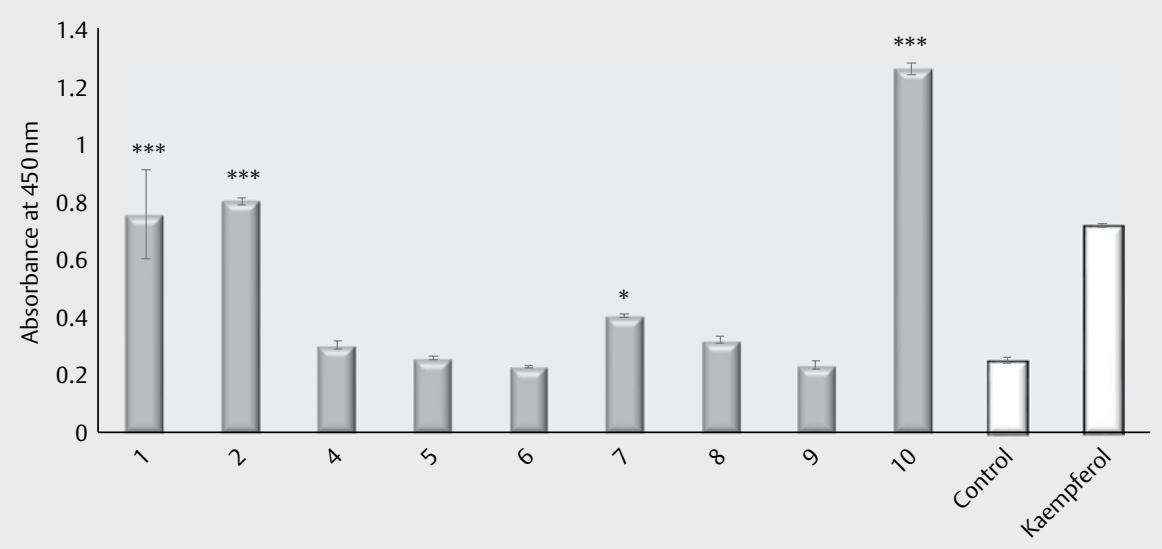

- Fig. 4 PPAR-y ligand-binding activity of 1, 2, and 4-10. PPAR-y ligand-binding activities of 1, 2, 4-10, and kaempferol were measured at a sample concentration of $0.5 \mathrm{mM}$. Data are represented as the mean \pm SEM of three experiments performed in triplicate; ${ }^{* * *} p<0.0001$ vs. control, $" p<0.01$ vs. control.

- Table $1{ }^{1} \mathrm{H}$ and ${ }^{13} \mathrm{C}$ NMR (500 and $125 \mathrm{MHz}, \mathrm{CDCl}_{3}$ ) spectroscopic assignments of 10 .

\begin{tabular}{|c|l|l|l|r|}
\hline Position & $\boldsymbol{\delta}_{\mathbf{H}}$ & & $\boldsymbol{J}(\mathbf{H z})$ & $\boldsymbol{\delta}_{\mathbf{C}}$ \\
\hline 1 & - & & & 129.2 \\
\hline 2 & 7.16 & $\mathrm{brd}$ & 2.5 & 142.2 \\
\hline 3 & 2.73 & $\mathrm{ddd}$ & $19.5,11.2,2.5$ & 30.5 \\
\hline & 2.20 & $\mathrm{~m}$ & & \\
\hline 4 & 2.89 & $\mathrm{~m}$ & & 33.4 \\
\hline 5 & 2.12 & $\mathrm{qd}$ & $12.4,5.0$ & 26.4 \\
\hline & 1.74 & $\mathrm{brd}$ & 12.4 & \\
\hline 6 & 2.54 & $\mathrm{ddd}$ & $16.9,2.3,2.0$ & 24.7 \\
\hline & 2.24 & $\mathrm{~m}$ & & \\
\hline 7 & - & & & 172.0 \\
\hline 8 & - & & & 131.8 \\
\hline 9 & - & & & 168.1 \\
\hline 10 & 7.16 & br d & 11.4 & 140.2 \\
\hline 11 & 6.35 & $\mathrm{ddd}$ & $15.0,11.4,1.1$ & 121.9 \\
\hline 12 & 6.09 & $\mathrm{ddd}$ & $15.0,7.1,0.6$ & 151.4 \\
\hline 13 & 2.44 & $\mathrm{sd}$ & $7.1,1.1$ & 31.9 \\
\hline 14 & 1.06 & $\mathrm{~d}$ & 6.7 & 22.0 \\
\hline 15 & 1.05 & $\mathrm{~d}$ & 6.7 & 22.0 \\
\hline 16 & 3.74 & $\mathrm{~s}$ & & 51.4 \\
\hline & & & & \\
\hline
\end{tabular}

$\mathrm{H}_{2} \mathrm{O}(3: 1 ; 4: 1 ; 5: 1)$ to yield $\mathbf{1}(44.8 \mathrm{mg}), \mathbf{2}(1.5 \mathrm{mg})$, and 3 (4.3 $\left.\mathrm{mg}\right)$. The MeOH-eluted portion $(120 \mathrm{~g})$ was chromatographed on silica gel $(2700 \mathrm{~g}, 45 \mathrm{~mm}$ i.d. $\times 430 \mathrm{~mm})$ eluted with $\mathrm{MeCN}-\mathrm{H}_{2} \mathrm{O}(1: 3 ; 1: 2$; $1: 1 ; 2: 1)$ to give 10 subfractions (Frs. a-j). Fr. a was subjected to a Sephadex LH-20 column ( $470 \mathrm{~g}, 25 \mathrm{~mm}$ i.d. $\times 300 \mathrm{~mm}$ ) eluted with $\mathrm{MeOH}-\mathrm{H}_{2} \mathrm{O}(1: 1 ; 2: 1)$ to give $4(58.0 \mathrm{mg}), 7(6.7 \mathrm{mg})$, and 8 $(17.0 \mathrm{mg})$. Fr. e was subjected to a Sephadex $\mathrm{LH}-20$ column $(470 \mathrm{~g}$, $25 \mathrm{~mm}$ i.d. $\times 300 \mathrm{~mm}$ ) eluted with $\mathrm{MeOH}-\mathrm{H}_{2} \mathrm{O}(2: 1)$ and a silica gel column eluted with $\mathrm{CHCl}_{3}-\mathrm{MeOH}-\mathrm{H}_{2} \mathrm{O}(100: 10: 1 ; 50: 10: 1 ; 30: 10: 1)$ to yield $\mathbf{5}(25.2 \mathrm{mg}), \mathbf{6}(6.2 \mathrm{mg})$, and $\mathbf{9}(7.1 \mathrm{mg})$. Fr. i was subjected to a Sephadex $\mathrm{LH}-20$ column $(470 \mathrm{~g}, 25 \mathrm{~mm}$ i.d. $\times 300 \mathrm{~mm}$ ) eluted with $\mathrm{MeOH}-\mathrm{H}_{2} \mathrm{O}(2: 1)$ and an ODS silica gel column eluted with $\mathrm{MeCN}-\mathrm{H}_{2} \mathrm{O}(2: 1)$ to yield $10(14.9 \mathrm{mg})$. Separation and isolation were guided a PPAR- $\gamma$ ligand-binding activity and TLC analysis of the fractions.( $>$ Fig. 1S-8S).

\section{Compound 10}

An amorphous solid; $[\alpha]_{\mathrm{D}}^{25}-0.22$ (c 0.10, $\left.\mathrm{CHCl}_{3}\right)$; IR $v_{\max }$ (film) $\mathrm{cm}^{-1}$ : $3414(\mathrm{OH}), 1700$ and $1644(\mathrm{C}=\mathrm{O}) ;{ }^{1} \mathrm{H}$ and ${ }^{13} \mathrm{C}$ NMR (500 and $125 \mathrm{MHz}, \mathrm{CDCl}_{3}$ ), see - Table 1; HR-ESI-TOF-MS (m/z: 301.1413 $[\mathrm{M}+\mathrm{Na}]^{+}$, calcd. for $\left.\mathrm{C}_{16} \mathrm{H}_{22} \mathrm{NaO}_{4}: 301.1416\right)$.

\section{Derivatization of $\mathbf{1 0}$}

A mixture of $10(0.5 \mathrm{mg})$ and BSTFA $(50 \mu \mathrm{L})$ in pyridine $(50 \mu \mathrm{L})$ was sealed in a glass vial and placed at $60^{\circ} \mathrm{C}$ for $3 \mathrm{~h}$. The reaction mixture was evaporated under a gentle stream of nitrogen to give the TMS derivative of $\mathbf{1 0 .}$

\section{PPAR-y ligand-binding activity}

PPAR-y agonist activity was examined using a nuclear receptor cofactor assay system (EnBio RCAS for PPAR- $\gamma$; EnBioTec Laboratories) according to the manufacturer's instructions. Briefly, a peptide of cyclic AMP response element-binding protein (CBP) was immobilized on the bottom of a microtiter plate. After adding the recombinant human PPAR- $y$ solution to the wells, DMSO (purity > 99.5\%) as a control, or a positive control or isolated compounds were added, respectively. The binding of the PPAR- $y$ ligand complex to the CBP on the plate was detected by measuring the absorbance at $450 \mathrm{~nm}$. This assay involves a cell-free system using nuclear receptors and cofactors. Pioglitazone (purity $>98.0 \%$ ) and kaempferol (purity $>97.0 \%$ ) were used as positive controls $(\mathrm{TCl})$. All other reagents or solvents used were of biochemical reagent grade.

\section{Statistical analyses}

Data are represented as the mean \pm standard error of the mean (SEM) of three experiments performed in triplicate. Dunnett's test was used and the level of significance is indicated by $p$ values. 


\section{Supporting information}

1D and 2D NMR and MS/MS spectra of $\mathbf{1 0}$ are available as Supporting Information.

\section{Acknowledgements}

We thank Hirokazu Ando and Yohei Sasaki for identifying E. sinica according to the ITS rDNA sequence.

\section{Conflict of Interest}

The authors declare that they have no conflict of interest.

\section{References}

[1] Ministry of Health Law, Japan The Japanese pharmacopoeia. 17th edition, Tokyo: Ministry of Health Law; 2016: 1589

[2] Minamizawa K, Goto H, Shimada Y, Terasawa K, Haji A. Effects of eppikahangeto, a Kampo formula, and Ephedrae herba against citric acid-induced laryngeal cough in guinea pigs. J Pharm Sci 2006; 101: $118-125$

[3] Abourashed EA, Alfy AT, Khan IA, Walker L. Ephedra in perspective - a current review. Phytother Res 2003; 17: 703-712

[4] Kim HK, Choi YH, Chang WT, Verpoorte R. Quantitative analysis of ephedrine analogues from Ephedra species using ${ }^{1} \mathrm{H}-\mathrm{NMR}$. Chem Pharm Bull 2003; 51: 1382-1385

[5] Amakura Y, Yoshimura M, Yamakami S, Yoshida T, Wakana D, Hyuga M, Goda Y. Characterization of phenolic constituents from Ephedra herb extract. Molecules 2013; 18: 5326-5334

[6] Nawwar MA, El-Sissi HI, Barakat HH. Flavonoid constituents of Ephedra alata. Phytochemistry 1984; 23: 2937-2939

[7] Shekelle P, Hardy ML, Morton SC, Maglione M, Suttorp M, Roth E, Jungvig L, Mojica WA, Gagné J, Rhodes S, McKinnon E. Ephedra and ephedrine for weight loss and athletic performance enhancement: Clinical efficacy and side effects. Evid Rep Technol Assess (Summ) 2003; 76: 1-4

[8] Kobayashi Y. Analgesic effects and side effects of ephedra herb extract and ephedrine alkaloids-free ephedra herb extract. Yakugaku Zasshi 2017; 137: 187-194
[9] Hyuga S, Hyuga M, Yoshimura M, Amakura Y, Goda Y, Hanawa T. Herbacetin, a constituent of ephedrae herba, suppresses the HGF-induced motility of human breast cancer MDA-MB-231 cells by inhibiting c-Met and Akt phosphorylation. Planta Med 2013; 79 : $1525-1530$

[10] Morales G, Sierra P, Mancilla A, Paredes A, Loyola LA, Gallardo O, Borquez J. Secondary metabolites from four medicinal plants from northern Chile: antimicrobial activity and biotoxicity against Artemia salina. J Chin Chem Soc 2003; 48: 13-18

[11] Cui EJ, Park JH, Park HJ, Chung IS, Kim JY, Yeon SW, Baek NI. Isolation of sterols from cowpea (Vigna sinensis) seeds and their promotion activity on HO-1. J Korean Soc Appl Biol Chem 2011; 54: 362-366

[12] Bernal F, Cuca L, Yamaguchi L. Coy-Barrera E. LC-DAD-UV and LC-ESI-MS-based analyses, antioxidant capacity, and antimicrobial activity of a polar fraction from Iryanthera ulei leaves. Rec Nat Prod 2013; 7: 152-156

[13] Kaouadji M, Morand JM, Garcia J. Further acylated kaempferol rhamnosides from Platanus acerifolia buds. J Nat Prod 1993; 56 : 1618-1621

[14] Si CL, Yu G], Du ZG, Huang XF, Fan S, Du HS, Hu WC. A new cis-pcoumaroyl flavonol glycoside from the inner barks of Sophora japonica L. Holzforschung 2016; 70: 39-45

[15] Rawat MSM, Prasad D, Joshi RK, Pant G. Proanthocyanidins from Prunus armeniaca roots. Phytochemistry 1999; 50: 321-324

[16] Kim IS, Park YJ, Yoon SJ, Lee HB. Ephedrannin A and B from roots of Ephedra sinica inhibit lipopolysaccharide-induced inflammatory mediators by suppressing nuclear factor-kB activation in RAW 264.7 macrophages. Int Immunopharmacol 2010; 10: 1616-1625

[17] Okitsu T, Sato K, Iwatsuka K, Sawada N, Nakagawa K, Okano T, Wada A. Replacement of the hydrophobic part of 9-cis-retinoic acid with cyclic terpenoid moiety results in RXR-selective agonistic activity. Bioorg Med Chem 2011; 19: 2939-2949

[18] Matsuo Y, Maeda S, Ohba C, Fukaya H, Mimaki Y. Vetiverianines A, B, and C: Sesquiterpenoids from Vetiveria zizanioides Roots. J Nat Prod 2016; 79: 2175-2180

[19] Long C, Kakiuchi N, Takahashi A, Komatsu K, Cai S, Mikage M. Phylogenetic Analysis of the DNA Sequence of the Non-Coding Region of Nuclear Ribosomal DNA and Chloroplast of Ephedra Plants in China. Planta Med 2004; 70: 1080-1084 